Funding: Australian Research Council (DP1(150101571)

0002-7693-194X

*Correspondence: $\underline{\text { r.cramp@uq.edu.au }}$

\section{Declarations}

Conflicts of interest/Competing interests: None

\title{
Physiological and morphological correlates of extreme acid tolerance in larvae of the acidophilic amphibian
}

\section{Litoria cooloolensis}

\author{
Edward A. Meyer ${ }^{1}$, Craig E. Franklin ${ }^{1}$ and Rebecca L. Cramp ${ }^{1 *}$ \\ ${ }^{I}$ School of Biological Sciences, The University of Queensland, \\ Brisbane, 4072 Australia
}

OrcID: Rebecca L Cramp: 0000-0001-9798-2271; Craig E Franklin: 0000-0003-1315-3797; Edward A Meyer: 0000-

Abstract: In the coastal sandy lowlands of east Australia, several anuran species including the Cooloola Sedgefrog Litoria cooloolensis, show remarkable tolerance to dilute highly acidic waters as low as $\mathrm{pH}$ 3.5. To investigate the physiological and morphological underpinnings of acid tolerance in L. cooloolensis larvae, we compared $\mathrm{Na}^{+}$balance, uptake and efflux rates, and gill and skin morphology in larvae reared in circum-neutral (pH 6.5) and pH 3.5 water. We hypothesised that acute exposure to $\mathrm{pH} 3.5$ water would cause an initial loss of ionic homeostasis in larvae, but with chronic exposure larvae would restore $\mathrm{Na}^{+}$balance. $\mathrm{Net}^{+}{ }^{+}$flux rates were not significantly different from zero in larvae reared at pH 3.5 and in acid-naïve animals maintained in pH 6.5 water. Animals reared at pH 6.5 and acutely exposed to $\mathrm{pH} 3.5$ exhibited a net loss of $\mathrm{Na}^{+}$, due to a significant inhibition of $\mathrm{Na}^{+}$uptake. In contrast, L. cooloolensis larvae reared at $\mathrm{pH} 3.5$ maintained $\mathrm{Na}^{+}$balance at $\mathrm{pH} 3.5$ and did not exhibit inhibition of $\mathrm{Na}^{+}$uptake at this $\mathrm{pH}$. Investigation of $\mathrm{Na}^{+}$transport kinetics and the morphology of the gills and integument suggests tolerance of $L$. cooloolensis larvae to low $\mathrm{pH}$ may be attributed to a high capacity for branchial $\mathrm{Na}^{+}$uptake, increased tight junction length and elevated mucus production in the gills and integument. These factors confer resistance to acid damage and disruption of ionic homeostasis which would otherwise result in the death of larvae exposed to waters of $\mathrm{pH} 4.0$ and less.

Key Words: wallum, junctions, sodium transport, epithelia, gills, calcium 
28 Availability of data and material: All data will be made available upon request to the authors

29 Code availability: not applicable

30 Authors' contributions: All authors contributed to the study conception and design. Material preparation, data collection

31 and analysis were performed by EAM and RLC. The first draft of the manuscript was written by EAM and all authors

32 commented on previous versions of the manuscript. All authors read and approved the final manuscript. 


\section{Abbreviations:}

35 ASW - artificial soft water

36 ICPOES / ICPMS - Inductively coupled plasma optical

37 emission spectroscopy/ Inductively coupled plasma

38 mass spectroscopy

39 MS222 - ethyl 3-aminobenzoate methanesulfonate

$40 \mathrm{~J}_{\mathrm{in}}-$ rate of $\mathrm{Na}^{+}$uptake

$41 \mathrm{~J}_{\text {out }}-$ rate of $\mathrm{Na}^{+}$efflux

$42 \mathrm{~J}_{\text {net }}-$ net $\mathrm{Na}^{+}$flux

43 Qout0 and Qout1 - total counts per minute in the flux

44 chambers at the beginning and end of the flux period,

45 respectively;

46 Qout - average amount of $\mathrm{Na}^{+}$in the flux bath during

47 the flux period

$48 \mathrm{~m}$ - dry mass of the tadpole

49 t- time

$50 \mathrm{~J}_{\max }-$ maximum $\mathrm{Na}^{+}$uptake rate

$51 \mathrm{~K}_{\mathrm{m}}-\mathrm{Na}^{+}$concentration at $50 \%$ of $\mathrm{J}_{\max }$

52 DBM - dry body mass

53 TEM - transmission electron micrograph

54 LM - Light micrograph

55 SEM - scanning electron micrograph

56 TJ - tight junction

57 MR - mitochondrion-rich cell

$58 \mathrm{ECaC}-$ epithelial $\mathrm{Ca}^{2+}$ channel
$59 \mathrm{ENaC}-$ epithelial $\mathrm{Na}^{+}$channel

60 MSV - mucus secretory vesicle

61 CCA - cell cross-sectional area

62 TMSVA - total cross-sectional area of mucus secretory

63 vesicles

64 bl - basal lamina

65 cap - capillary

$66 \mathrm{cc}$ - ciliated cell

67 ct - connective tissue

$68 \mathrm{~d}$ - desmosome

69 ec-squamous epithelial cell of outer integument

$70 \mathrm{fp}$ - filter plates

71 ga - gill arch

$72 \mathrm{gt}$ - gill tuft

73 hd - hemi-desmosome

$74 \mathrm{mf}$ - mucus fuzz

$75 \mathrm{mr}$ - microridge

$76 \mathrm{mt}$ - mitochondria

$77 \mathrm{n}$ - nucleus

$78 \mathrm{pc}$ - pavement cell

79 rbc - red blood cell

$80 \mathrm{tj}$ - tight junction

81 v - velum 
bioRxiv preprint doi: https://doi.org/10.1101/2019.12.15.872259; this version posted January 28, 2020. The copyright holder for this preprint (which was not certified by peer review) is the author/funder, who has granted bioRxiv a license to display the preprint in perpetuity. It is made available under aCC-BY-NC-ND 4.0 International license. 


\section{Introduction}

For fish and aquatic amphibian larvae, survival in acidic waters presents a significant challenge with waters $\leq$ pH 5.0 inhibiting active $\mathrm{Na}^{+}$uptake, damaging gill epithelia, and increasing diffusive efflux of electrolytes across the gills and integument (Ferreira and Hill, 1982; Freda and Dunson, 1984; Freda et al., 1991; McDonald, 1983; Meyer et al., 2010). Damage to the gills of fish and amphibian larvae exposed to low $\mathrm{pH}$ includes lifting of the branchial epithelium, dilation of paracellular spaces and opening/shortening of tight junctions between gill pavement cells (Daye and Garside, 1976; Meyer et al., 2010; Rosseland and Staurnes, 1994). The exposure of fish and amphibian larvae to low $\mathrm{pH}$ water can also result in significant damage to the integument (e.g. tight junction damage and cell swelling and sloughing and localised necrosis) and in amphibian larvae, it is the integument which appears most sensitive to acid damage (Daye and Garside, 1976; Meyer et al., 2010). With the structural integrity of epithelia compromised, transepithelial resistance to ionic efflux is greatly reduced. The resultant net loss of plasma electrolytes (in particular $\mathrm{Na}^{+}$) can lead to substantial ionic and osmotic disturbances, with the loss of $50 \%$ of body $\mathrm{Na}^{+}$resulting in death (Freda and Dunson, 1984; Freda et al., 1991; Laurent and Perry, 1991; McDonald, 1983; Meyer et al., 2010; Milligan and Wood, 1982; Rosseland and Staurnes, 1994). Problems with electrolyte loss appear to be exacerbated in soft (Ca ${ }^{2+}$-poor) waters where reduced availability of $\mathrm{Ca}^{2+}$ promotes diffusive ionic efflux (Freda and Dunson, 1984; McDonald, 1983). species tolerate acidic conditions remarkably well (Gonzalez et al., 2002). In the coastal sandy lowlands of east Australia, surface waters are naturally soft and acidic with low concentrations of key electrolytes such as $\mathrm{Na}^{+}$and $\mathrm{Cl}^{-}$ (Bensink and Burton, 1975; Hines and Meyer, 2011). With relatively soft waters of such low pH, the maintenance of ionic homeostasis and survival in these areas presents a significant challenge to aquatically respiring animals. Yet despite this, frog species endemic to these regions breed successfully in soft waters of $\leq \mathrm{pH} 4.0$ (Hines and Meyer, 2011; Ingram and Corben, 1975). Like animals from other naturally acidic environments, e.g., fish from the ion-poor acidic Rio Negro (Gonzalez et al., 1997), larvae of these frogs appear be able to resist the damaging actions of acidic soft waters. native to the Rio Negro) has attracted considerable interest (Gonzalez et al., 1997; Gonzalez and Preest, 1999; Gonzalez and Wilson, 2001; Gonzalez et al., 2002; Wilson et al., 1999; Wood et al., 2003). In these animals, acid tolerance is conferred by physiological and/or morphological mechanisms that allow animals to resist or compensate for the 
111 disruption of ionic homeostasis and associated damage to the gills (Gonzalez et al., 1997; Gonzalez and Dunson, 1989b;

112 Gonzalez and Preest, 1999). In acid tolerant fish, resistance to low $\mathrm{pH}$ has been linked to a high branchial affinity for

$113 \mathrm{Na}^{+}$and/or increased rates of $\mathrm{Na}^{+}$uptake, allowing for the maintenance of $\mathrm{Na}^{+}$uptake at low pHs (Gonzalez et al., 1997;

114 Gonzalez and Preest, 1999). Tolerance of fish to acid exposure has also been linked to the control of paracellular ion

115 permeability, with greater branchial tight junction length correlated with resistance to increased ionic efflux at low $\mathrm{pH}$

116 (McDonald et al., 1991). Studies of acid tolerant fish also suggest that control of ionic efflux at low pH may be linked to

117 a high branchial affinity for $\mathrm{Ca}^{2+}$, with $\mathrm{Ca}^{2+}$ playing an important role in maintaining transepithelial resistance (Gonzalez

118 et al., 1997; Gonzalez and Preest, 1999). In addition, resistance to acid damage and control of branchial ionic efflux at

119 low $\mathrm{pH}$ has also been tied to increased mucus production at the gills with increased mucus secretion likely to protect

120 branchial epithelia and tight junctions from acid damage (Jagoe and Haines, 1983; McDonald, 1983; McDonald et al.,

121 1991).

122 By comparison, very little has been published on acid tolerance in amphibian species, with studies on anuran

123 larvae dealing mainly with effects of short-term (acute) acid exposure on ion regulation in acid-sensitive species (Freda

124 and Dunson, 1984; McDonald et al., 1984; Meyer et al., 2010). These studies tell us little about the mechanisms

125 underpinning extreme soft water acid tolerance in acidophilic frog species. In this study we investigated physiological

126 and morphological mechanisms for extreme acid tolerance in the Cooloola sedgefrog (Litoria cooloolensis), one of a

127 number of frog species endemic to the wallum of coastal eastern Australia, an area of sand plains and dunes with

128 swamps and lakes containing dilute (low $\left.\mathrm{Na}^{+}\right)$and soft $\left(\right.$low $\mathrm{Ca}^{2+}$ ) water as acidic as $\mathrm{pH} 3.0$ (Hines and Meyer, 2011).

129 We hypothesised that relative to a closely-related but acid sensitive species, Litoria fallax (Meyer et al., 2010), larvae of

130 the acid tolerant L. cooloolensis would exhibit distinct physiological and morphological traits that would permit the

131 maintenance of ionic homeostasis at low $\mathrm{pH}$ and permit habitation of these extreme environments.

133 Materials and Methods

134 Experimental animals

135 Larvae used in laboratory experiments were reared from spawn collected from four pairs of amplectant $L$.

136 cooloolensis captured at Lake Poona, Cooloola National Park and Brown Lake, North Stradbroke Island (Queensland,

137 Australia). All amplectant animals were released at the point of capture following the collection of spawn. Water 
samples from capture sites were collected and analysed by ICPOES / ICPMS (School of Agriculture and Food Sciences, The University of Queensland; Table 1).

\section{Effects of acute and chronic exposure to low $\mathrm{pH}$ on body $\mathrm{Na}^{+}$and water contents}

To assess the sensitivity of larvae to acute acid exposure, twenty acid naïve larvae were removed from their holding tubs and placed in separate $250 \mathrm{~mL}$ glass beakers filled with fresh $\mathrm{pH} 6.5 \mathrm{ASW}$. Ten acid-acclimated larvae were also removed from holding tanks and placed into individual beakers containing fresh pH 3.5 ASW. After 24 hours, the $\mathrm{pH}$ of water in half of the beakers containing acid naïve larvae was acutely lowered to $3.5 \pm 0.05$ through the addition $0.1 \mathrm{M}$ sulphuric acid. The $\mathrm{pH}$ of the water of remaining naïve larvae and the acid acclimated larvae was not changed. Every half hour thereafter, larval survival was assessed and dead larvae were immediately removed from beakers, blotted dry, weighed and analysed for tissue $\mathrm{Na}^{+}$content (below). After 24 hours, all surviving larvae were sacrificed with ethyl 3-aminobenzoate methanesulfonate (MS 222; diluted 1:2000), blotted dry, weighed and analysed

162 for tissue $\mathrm{Na}^{+}$content. For the determination of body $\mathrm{Na}^{+}$content, larvae were placed into pre-weighed, acid-washed 163 glass test tubes and dried to a constant mass at $95{ }^{\circ} \mathrm{C}$ and re-weighed. Tissue water content (\%) was determined by 164 subtracting the larval dry mass from the wet mass. Dried larvae were then dissolved in $3 \mathrm{~mL}$ of concentrated nitric acid. 165 After three days, $1 \mathrm{~mL}$ of digest was placed into an acid-washed plastic tube and eight $\mathrm{mL}$ of distilled water was then 
added to the digest in test tube and the $\mathrm{Na}^{+}$concentration of diluted samples determined via plasma-coupled atomic emission spectroscopy (Queensland Health Laboratories, Nathan, QLD, Australia).

\section{$\mathrm{Na}^{+}$transport measurements}

For acid naïve larvae, rates of $\mathrm{Na}^{+}$uptake $\left(\mathrm{J}_{\text {in }}, \mathrm{Na}^{+}\right.$efflux $\left(\mathrm{J}_{\text {out }}\right)$ and net $\mathrm{Na}^{+}$flux $\left(\mathrm{J}_{\text {net }}\right)$ were measured at both their acclimation $\mathrm{pH}(6.5)$ and following acute exposure to $\mathrm{pH} 3.5$ water. $\mathrm{Na}^{+}$fluxes were measured in acid acclimated

172 larvae at their acclimation $\mathrm{pH}$ of 3.5 only. Larvae were left overnight in individual $40 \mathrm{~mL}$ glass flux chambers

173 connected to a $15 \mathrm{~L}$ re-circulating system and supplied with pH 6.5 (acid naïve larvae) or $\mathrm{pH} 3.5$ (acid acclimated

174 larvae) ASW at a rate of $20 \mathrm{~mL} \mathrm{~h}^{-1}$. The following morning, flow to all chambers was stopped and $15 \mathrm{kBq} \mathrm{L}^{-1}$ of ${ }^{22} \mathrm{NaCl}$

175 was added to each chamber; for the measurement of $\mathrm{Na}^{+}$fluxes in acid naïve larvae at $\mathrm{pH} 3.5$, dilute $0.1 \mathrm{M}$ sulphuric acid was added to chambers prior to the addition of ${ }^{22} \mathrm{NaCl}$. After $5 \mathrm{~min}$, an initial $10 \mathrm{~mL}$ water sample was withdrawn

177 from each chamber. An hour later a second $10 \mathrm{~mL}$ water sample was withdrawn and tadpoles were removed from flux 178 chambers. Larvae were rinsed in unlabelled ASW water and transferred to $7 \mathrm{~mL}$ plastic test tubes for direct counting in an LKB 1277 Gamma Master (LKB Wallac, Turku, Finland). Water samples were similarly assayed for ${ }^{22}$ Na-activity and then analysed for $\mathrm{Na}^{+}$concentration via ICAEP. Net $\mathrm{Na}^{+}$flux $\left(\mathrm{J}_{\text {net }}\right), \mathrm{Na}^{+}$uptake $\left(\mathrm{J}_{\text {in }}\right)$, and $\mathrm{Na}^{+}$loss $\left(\mathrm{J}_{\text {out }}\right)$, were calculated following Gonzalez et al. (1997):

$$
J_{\text {net }}=\frac{\left([\mathrm{Na}]_{1}-[\mathrm{Na}]_{2}\right) V}{m \times t}
$$

where $[\mathrm{Na}]_{1}$ and $[\mathrm{Na}]_{2}$ are the $\mathrm{Na}^{+}$concentrations in the flux champers at the beginning and end of the flux period (in mmol L $\left.{ }^{-1}\right), \mathrm{V}$ is the flux chamber volume in $\mathrm{L}, \mathrm{m}$ is the mass of the tadpole in grams and $\mathrm{t}$ in the time in hours. $\mathrm{Na}^{+}$ influx ( $\left.\mathrm{J}_{\text {in }}\right)$ was calculated following Gonzalez et al. (1997):

$$
J_{\text {in }}=\left[\left(\ln Q_{\text {out } 0}-\ln Q_{\text {out } 1}\right) Q_{\text {out }}\right] / m \times t
$$

where $\mathrm{Q}_{\text {out }}$ and $\mathrm{Q}_{\text {out }}$ are the total counts per minute in the flux chambers at the beginning and end of the flux period, respectively; $Q_{\text {out }}$ is the average amount of $\mathrm{Na}^{+}$in the flux bath during the flux period, $\mathrm{m}$ is the mass of the tadpole in grams and $t$ is the time in hours. $\mathrm{J}_{\text {out }}\left(\mathrm{Na}^{+}\right.$efflux rate) was calculated as the difference between $\mathrm{J}_{\text {net }}$ and $\mathrm{J}_{\text {in }}$. Data were normalised to total dry body mass (DBM). 
191 External calcium concentrations were adjusted to approximately twice and ten times the amount of $\mathrm{Ca}^{2+}$ in ASW (i.e.,

192 with $\left[\mathrm{Ca}^{2+}\right]=0.04,0.08$ and $0.4 \mathrm{mmol} \mathrm{L}^{-1}$ ) in the flux chambers immediately prior to the reduction in chamber $\mathrm{pH}$ and

193 the addition of the radioisotope. $\mathrm{Na}^{+}$efflux rates were calculated as detailed above.

$\mathrm{Na}^{+}$transport kinetics (affinity and maximum uptake rates) were assessed by measuring the dependence of $\mathrm{Na}^{+}$

uptake on environmental $\mathrm{Na}^{+}$concentrations in both larvae reared at $\mathrm{pH} 6.5$ and $\mathrm{pH} 3.5$. All measurements were made at pH 6.5. Prior to measurements, larvae were isolated overnight in glass beakers containing $200 \mathrm{~mL}$ ASW at $\mathrm{pH}$ 6.5. The following morning, tadpoles were transferred to glass beakers with $50 \mathrm{~mL}$ radiolabelled $\mathrm{pH} 6.5 \mathrm{ASW}\left({ }^{22} \mathrm{NaCl}: 15 \mathrm{kBq} \mathrm{L}\right.$

${ }^{1}$ ) with $\mathrm{Na}^{+}$concentrations ranging from $0.05 \mathrm{mmol} \mathrm{L}^{-1}$ through to $3.5 \mathrm{mmol} \mathrm{L}^{-1}$ (the concentration of $\mathrm{Na}^{+}$was modified through the omission or addition of $\mathrm{NaCl}$ from or to ASW). Five to seven larvae of each species were exposed to each of five different sodium concentrations. After $1 \mathrm{~h}$, tadpoles were removed from beakers and rinsed in unlabelled $\mathrm{pH} 6.5$ water for 1 min each. Thereafter tadpoles were counted using a Packard gamma counter. The transport mechanism's

202 affinity for $\mathrm{Na}^{+}\left(\mathrm{K}_{\mathrm{m}}\right)$, and maximum transport capacity, $\mathrm{J}_{\mathrm{max}}$, were estimated using non-linear regression. The regression 203 model for estimating these parameters was:

$$
y=\frac{a x}{(b+x)}
$$

204 where $\mathrm{y}=\mathrm{J}_{\mathrm{in}}, a=\mathrm{J}_{\max } ; b=\mathrm{K}_{\mathrm{m}}$ and $x=\left[\mathrm{Na}^{+}\right]_{\mathrm{e}}$ (the concentration of $\mathrm{Na}^{+}$in bath water). Data were normalised to total dry 205 body mass (DBM).

\section{Morphological Analyses}

Gills and integument of L. cooloolensis larvae reared from embryos at $\mathrm{pH} 6.5$ and $\mathrm{pH} 3.5$ (Gosner stage 25- 29) were examined under light (LM), transmission electron (TEM) and scanning electron microscopes (SEM). Gills and a

210 section of tail were excised from larvae sacrificed with MS222 (1:2000). Tissues for LM were fixed in 10\% neutral 211 buffered formaldehyde for $24 \mathrm{~h}$, dehydrated and cleared with ethanol and xylene, respectively, and embedded in paraffin 212 wax. Blocks were sectioned at $6 \mu \mathrm{m}$ and stained with hematoxylin and eosin. Tissues for TEM were fixed for $2 \mathrm{~h}$ in cold $2132.5 \%$ glutaraldehyde in $0.1 \mathrm{M}$ cacodylate buffer. Tissues were post-fixed in osmium tetroxide ( $1 \%$ solution in $0.1 \mathrm{M}$ 214 cacodylate buffer), dehydrated in an ascending ethanol series and embedded in Spurr's resin. Ultrathin sections were 215 stained in lead citrate and uranyl acetate, and viewed and photographed with a Hitachi 300 TEM operating at $75 \mathrm{kV}$ 216 (Meyer et al. 2010). For SEM, tissue samples were fixed for $2 \mathrm{~h}$ in $2.5 \%$ glutaraldehyde in $0.1 \mathrm{M}$ cacodylate buffer, 
217 dehydrated in ethanol and critical point dried with liquid $\mathrm{CO}_{2}$ (Polaron; ProSciTech, Thuringowa, QLD, Australia).

218 Whole gills, gill arches and tail sections from acid naïve and acid acclimated larvae $(\mathrm{N}=3$ for each group) were

219 mounted on stubs and coated with gold in a sputter coater (SPI Module; SPI Supplies, West Chester, PA, USA). Gills

220 and tail sections were viewed and photographed with a Jeol JSM 6400 SEM.

221 The gross morphology of gill tufts and the integument was viewed using SEM and LM. A qualitative

222 assessment, based on SEM and LM examination of tissues, was made of gill tuft proportions (height and thickness),

223 lymphatic/paracellular space, and thickness of the integument. Gill tuft sections were viewed at low power (5000 - 10

$224000 \mathrm{x}$ magnification) with a Hitachi 300 transmission electron microscope operating at $75 \mathrm{kV}$. Intercellular junctions

225 were measured quantitatively from digital TEM images using a Warcom graphics tablet and image analysis software

226 (SigmaScanPro $\left.{ }^{\mathrm{TM}}\right)$. The junctional attributes measured were total length of the junctional complex between cells

227 (including both the tight and adherens junctions, tight junction length, minimum width (the distance between adjacent

228 cell membranes within the tight junction) and maximum width (the distance between apposing cell membranes within

229 the adherens junction). Gill tuft pavement cells (between 10 and 15 per animal) and epithelial cells of the integument

230 (between 10 and 15 per animal) were examined using TEM and the abundance of patent mucus secretory vesicles at the

231 apical surface of cells, secretory vesicle cross-sectional area and cell cross-sectional areas were measured

232 (SigmaScanPro $\left.{ }^{\mathrm{TM}}\right)$.

\section{Statistical analyses}

Mean body $\mathrm{Na}^{+}$and water contents were compared using t-tests. Mean $\mathrm{J}_{\text {net }}, \mathrm{J}_{\text {in }}$ and $\mathrm{J}_{\text {out }}$ of acid naïve and acid

acclimated larvae at their acclimation $\mathrm{pH}$ and in acid naïve larvae acutely exposed to $\mathrm{pH} 3.5$ ASW were compared using

237 one-way ANOVA and Sidak post-hoc tests. Mean $\mathrm{J}_{\text {net }}$ values were judged significantly different from zero using one

238 sample means t-tests. A linear mixed-effects model with Tukeys post-hoc tests was used to compare mean $\mathrm{J}_{\text {out }}$ at

239 different calcium concentrations across acclimation treatments. Where necessary, data were log or arcsine-square root

240 transformed prior to analysis. For the morphological variables, we sought to identify morphological differences between

241 acid naïve and acid acclimated larvae reflecting acclimation or a capacity for morphological plasticity with chronic

242 exposure to $\mathrm{pH} 3.5$ soft water. All morphological parameters were compared using t-tests $(\alpha=0.05)$. Unless otherwise

243 stated all values reported are means \pm s.e. Analyses were conducted using GraphPad Prism 8.3. 


\section{Results}

\section{6}

247

248

249

250

251

252

253

254

255

\section{Survivorship, body $\mathrm{Na}^{+}$and water contents}

Acid naïve $L$. cooloolensis larvae acutely exposed to $\mathrm{pH} 3.5$ water suffered $20 \%$ mortality after 24 hours;

however, acid naïve and acid acclimated larvae maintained at their acclimation $\mathrm{pH}$ experienced no mortality during this period. The body $\mathrm{Na}^{+}$content of acid-naïve larvae acutely exposed to $\mathrm{pH} 3.5$ water was significantly lower than that of larvae maintained at $\mathrm{pH} 6.5$, indicating a net loss of body $\mathrm{Na}^{+}$. Acid-naïve larvae acutely exposed to $\mathrm{pH} 3.5$ that died within $24 \mathrm{~h}$ had lost $>60 \%$ of total body $\mathrm{Na}^{+}\left(388 \pm 20 \mu \mathrm{mol} \mathrm{Na}^{+} \mathrm{g}^{-1} \mathrm{DBM}\right)$, while those that survived for $24 \mathrm{~h}$ at $\mathrm{pH}$ 3.5 lost on average $35 \%$ of their body $\mathrm{Na}^{+}\left(620 \pm 30 \mu \mathrm{mol} \mathrm{Na}^{+} \mathrm{g}^{-1} \mathrm{DBM} ; t=5.54, d f=27, P<0.001\right)$. The total body $\mathrm{Na}^{+}$content of $L$. cooloolensis larvae reared at pH 3.5 was slightly( $\left.11 \%\right)$, but not significantly lower than that of larvae reared at pH $6.5\left(862 \pm 45\right.$ and $969 \pm 55 \mu \mathrm{mol} \mathrm{Na}^{+} \mathrm{g}^{-1}$ dry body mass [DBM], respectively; $t=1.7, d f=27, P=$ 0.1). Body water contents did not differ significantly between $\mathrm{pH}$ treatments, with water comprising approximately $90 \%$ of wet body mass of all larvae. The dry mass of gills (as a percentage of dry body mass) was not significantly different between acid naïve and acid acclimated larvae $(0.62 \pm 0.09$ and $0.76 \pm 0.06 \%$, respectively).

\section{$\mathrm{Na}^{+}$fluxes}

For acid naïve larvae tested at pH 6.5 rates of $\mathrm{Na}^{+}$uptake $\left(\mathrm{J}_{\text {in }}\right)$ and efflux $\left(\mathrm{J}_{\text {out }}\right)$ were roughly equal such that $\mathrm{J}_{\text {net }}$ was not significantly different from zero (acid naïve: $t=1.12, d f=5, P=0.32$; Fig 1a). This was also the case for acid acclimated larvae tested at $\mathrm{pH} 3.5$ (acid acclimated: $t=2.4, d f=6, P=0.06$ ). Mean $\mathrm{Na}^{+}$influx rates for acid acclimated larvae at pH 3.5 were slightly (20\%), but not significantly, higher than those of acid naïve larvae at $\mathrm{pH} 6.5\left(\mathrm{~J}_{\mathrm{in}}: t=1.77\right.$, $d f=15, P=0.18)$. However, rates of $\mathrm{Na}^{+}$efflux were $\sim 30 \%$ higher in acid acclimated larvae $\left(\mathrm{J}_{\text {out }}: t=3.28, d f=15, P=\right.$ 0.01). Relative to larvae at $\mathrm{pH} 6.5$, acute exposure of acid naïve larvae to $\mathrm{pH} 3.5$ water resulted in a $50 \%$ decrease in $\mathrm{Na}^{+}$ uptake rate $(t=6.23, d f=15, P<0.001)$ but had no effect on $\mathrm{Na}^{+}$efflux rates $(t=0.92, d f=18, P=0.62)$. This reduction in uptake resulted in a significant net loss of $\mathrm{Na}^{+}(t=3.77, d f=6, P=0.009)$.

$\mathrm{pH}$ acclimation group $\left(F_{(1,17)}=39.39, P<0.001\right)$ and water calcium concentrations had significant main effects on $\mathrm{Na}^{+}$efflux rates in L. cooloolensis larvae $\left(F_{(2,17)}=19.15, P<0.001\right)$; there was also a significant interaction between the two factors $\left(F_{(2,14)}=4.72, P=0.027\right)$. In both acid naïve and acid acclimated larvae, $\mathrm{Na}^{+}$efflux rates at $\mathrm{pH} 3.5$ were unaffected by increasing water calcium levels to $80 \mu \mathrm{M}$, but were significantly reduced by 66 and 35\% respectively 
272 (compared to $40 \mu \mathrm{M} \mathrm{Ca}^{2+}$ ), when $\left[\mathrm{Ca}^{2+}\right]_{\mathrm{e}}$ was increased to $400 \mu \mathrm{M}$ (acid naïve: $q=9.4, d f=31, P<0.001$; acid

273 acclimated: $q=3.5, d f=31, P=0.048$; Fig 1b).

274 In all larvae, $\mathrm{Na}^{+}$uptake increased with increasing water $\mathrm{Na}^{+}$content $\left(\left[\mathrm{Na}^{+}\right]_{\mathrm{e}}\right) . \mathrm{J}_{\max }$ of acid acclimated larvae at 275 pH $6.5\left(210.6 \pm 26.32 \mu \mathrm{mol} \mathrm{Na}^{+} \mathrm{g}^{-1} \mathrm{DBM} \mathrm{h}^{-1}\right)$ was significantly greater than that of acid naïve L. cooloolensis larvae at

276 pH $6.5\left(131.8 \pm 18.72 \mu \mathrm{mol} \mathrm{Na}^{+} \mathrm{g}^{-1} \mathrm{DBM} \mathrm{h}^{-1} ; F_{(1,62)}=4.29, P=0.042\right)$. However, the $\mathrm{K}_{\mathrm{m}}$ of acid acclimated larvae

$277\left(1648 \pm 543.6 \mu \mathrm{mol} \mathrm{l}^{-1}\right)$ was not significantly different from that of acid naïve L. cooloolensis larvae $(1990 \pm 529.1 \mu \mathrm{mol}$

$278 \quad \mathrm{I}^{-1} ; F_{(1,62)}=0.17, P=0.68 ;$ Fig $\left.1 \mathrm{c}\right)$.

\section{Gill and Integument morphology}

The gills of both acid acclimated and acid naïve L. cooloolensis larvae were structurally very similar. The gills comprised four arches with thin-walled, vascularised tufts projecting ventrally from each arch and filter plates situated dorsally (Fig. 2a). The epithelium of gill tufts comprised a single layer of flattened pavement cells and mitochondrionrich (MR) cells held together by tight and adherens junctions and desmosomes (Figs. 2b-f). Pavement cells, the dominant cell type, were generally flat. Visible within the cytoplasm of these cells were mitochondria and numerous mucus secretory vesicles. Mucus released from these vesicles adhered to the surface of gill tufts. Dark-staining MR cells, which were few in number, were packed with mitochondria and contained few mucus secretory vesicles. The thickness of the gill tuft epithelium and gill tuft proportions (thickness and relative length) were similar in both acid naïve and acid acclimated larvae.

The epidermis of $L$. cooloolensis larvae consisted of a double layer of flattened squamous epithelial cells above a basal lamina (Fig. 2g). The apical membrane of cells in the outer epidermis was amplified with microridges (pavement cells) and microvilli and, in some cases, cilia as well (Fig. 2h). Epidermal cells were held together by desmosomes and tight junctions (Fig. 2i). Cells of the basal layer were attached to the basal lamina by half-desmosomes (Fig. 2j). Cells of the outer layer contained numerous mucus secretory vesicles (Fig. 2k). Electron-dense mucus released from these vesicles adhered to the apical surface of cells. 
were significantly greater in both the gills and integument of acid-acclimated larvae (Table 3). Electron-dense mucus released from mucus secretory vesicles adhered to the apical surface of cells (Fig 4d). MSV density, total MSV crosssection area and the number of patent mucus vesicles were all higher in acid acclimated larvae compared with acid naïve larvae. The total cross-sectional area of MSVs of acid acclimated larvae was over twice that of acid naïve larvae. The density of patent MSVs at the gill surface was over three times that of acid naïve larvae.

\section{Discussion}

The tolerance of $L$. cooloolensis embryos and larvae to waters of low $\mathrm{pH}$ is unusual amongst amphibians, with acid waters $\leq \mathrm{pH} 4$ causing significant embryonic and larval mortality in most other species (see Freda, 1986; Rowe and Freda, 2000). The capacity of L. cooloolensis larvae to withstand chronic exposure to dilute waters as acidic as $\mathrm{pH} 3.5$ is particularly noteworthy and on a par with fish species native to the extremely ion-poor and acidic Rio Negro (Gonzalez et al., 1997; Gonzalez and Dunson, 1989b; Gonzalez and Preest, 1999) and acidic lakes of Japan (Hirata et al., 2003). Compared to the closely related acid-sensitive sibling species, Litoria fallax (Meyer et al 2010), the capacity for survival at low $\mathrm{pH}$ in L. cooloolensis larvae may be a combination of both inherent species-specific traits and physiological plasticity. to pH 3.5 water resulted in $100 \%$ mortality within $24 \mathrm{~h}$ (Meyer et al. 2010) compared with $20 \%$ in acid naïve $L$. coolooensis larvae acutely exposed to $\mathrm{pH} 3.5$. Although exposure to $\mathrm{pH} 3.5$ water did result in a substantial reduction in loss in moribund L. fallax larvae. As with previous studies (Freda and Dunson, 1984; Freda and Dunson, 1986a; Freda 321 and Dunson, 1986b; McDonald et al., 1984; Meyer et al., 2010), those L. cooloolensis larvae that lost more than 50\% of 322 their body $\mathrm{Na}^{+}$died. While the average body sodium content of larvae reared at $\mathrm{pH} 3.5$ was slightly lower than that of 323 larvae maintained at $\mathrm{pH}$ 6.5, flux data indicate no net loss of body $\mathrm{Na}^{+}$at this $\mathrm{pH}$, with acid acclimated animals able to 324 resist inhibition of $\mathrm{Na}^{+}$uptake at $\mathrm{pH} 3.5$ (unlike acid naïve larvae which suffered significant inhibition of $\mathrm{Na}^{+}$uptake at $325 \mathrm{pH} 3.5)$. 
2010). In these species, the net loss of body $\mathrm{Na}^{+}$can significantly disrupt ionic homeostasis causing larvae to die (see,

e.g., Meyer et al., 2010). Survival of amphibian larvae at such low pHs therefore requires the regulation of both $\mathrm{Na}^{+}$

efflux and uptake rates, such that ionic homeostasis is maintained. Acute exposure of acid-sensitive amphibian larvae to

331 low $\mathrm{pH}$ water exacerbates rates of $\mathrm{Na}^{+}$efflux likely as a result of the disruption of epithelial paracellular junctions

332 (Meyer et al., 2010). In previous studies, elevated $\mathrm{Na}^{+}$loss at low $\mathrm{pH}$ has been attributed to the opening and shortening

333 of epithelial tight junctions promoting the paracellular efflux of $\mathrm{Na}^{+}$ions (Ferreira and Hill, 1982; Freda and Dunson,

334 1984; Freda et al., 1991; McDonald, 1983; Meyer et al., 2010). The comparatively low rates of $\mathrm{Na}^{+}$efflux in $L$.

335 cooloolensis larvae acutely and chronically exposed to $\mathrm{pH} 3.5$ water suggest that the functional integrity of these

336 junctions was unaffected by prolonged acid exposure (Ferreira and Hill, 1982; Freda and Dunson, 1984; Freda et al.,

337 1991; McDonald, 1983; Meyer et al., 2010). Resistance of acid acclimated L. cooloolensis larvae to increased $\mathrm{Na}^{+}$efflux

338 at low pH may be attributed to an increase in epithelial apical junctional complex (tight junction, adherens junction and

339 desmosome) length in both the skin and gills, and an increase in tight junction length in epithelial cells of the gills.

340 However, epithelia junction length may not necessarily be a good predictor of acid tolerance in amphibians, since

341 junctional lengths of acid sensitive L. fallax larvae (Meyer et al., 2010) are in fact significantly longer than those of acid-

342 naïve L. cooloolensis larvae and on par with those of acid acclimated L. cooloolensis. The improved resistance of $L$.

343 cooloolensis larvae (compared with L. fallax) to increased efflux may be linked to better apposition of gill epithelial

344 cells, with junctional widths greater in acid-sensitive L. fallax larvae compared with L. cooloolensis larvae (Meyer et al.,

345 2010). Differences both between these species and between acid acclimated and acid naïve L. cooloolensis (in regards to

346 their ability to resist increased $\mathrm{Na}^{+}$efflux at low $\mathrm{pH}$ ) could also be related to the composition of junctional proteins

347 linking epithelial cells, with shifts in the composition of junctional proteins such as claudins and occludin having been

348 shown to correlate with a decrease in $\mathrm{Na}^{+}$efflux during low $\mathrm{pH}$ exposure in zebrafish (Kumai et al. 2011). Further

349 work is required to determine if changes in these proteins also accompany acclimation/adaptation to low $\mathrm{pH}$ in $L$.

350 cooloolensis larvae.

351 Protection of epithelial junction integrity during low $\mathrm{pH}$ exposure is well known to be influenced by external

$352\left[\mathrm{Ca}^{2+}\right]$. In the current study, water $\left[\mathrm{Ca}^{2+}\right]$ significantly influenced $\mathrm{Na}^{+}$efflux rates at low $\mathrm{pH}$ in both acid naïve and acid

353 acclimated L. cooloolensis larvae, indicating that $\left[\mathrm{Ca}^{2+}\right]_{\mathrm{e}}$ is likely involved in maintaining junctional integrity. Provision

354 of additional calcium offset some of the effects of $\mathrm{pH}$ on $\mathrm{Na}^{+}$efflux rates suggesting that calcium handling (i.e. binding

355 to junctional proteins, transcellular uptake) may be compromised at low $\mathrm{pH}$. A similar protective effect of elevated 
$356\left[\mathrm{Ca}^{2+}\right]_{\mathrm{e}}$ has been demonstrated for larval Rana pipens where $\mathrm{Na}^{+}$efflux rates were suppressed almost completely $(87 \%)$

357 following acute exposure to high $\mathrm{Ca}^{2+}$, low pH water (Freda and Dunson, 1984). Likewise, studies of acid tolerant fish

358 have shown that in most cases, the presence of elevated $\left[\mathrm{Ca}^{2+}\right]_{\mathrm{e}}$ levels reduces $\mathrm{Na}^{+}$efflux rates in waters of low $\mathrm{pH}$,

359 resulting in substantially reduced mortality rates (Glynn et al., 1992; Gonzalez and Dunson, 1989a; Gonzalez et al.,

360 1998; Matsuo and Val, 2002; McWilliams, 1983; see also review by Walker et al., 1988). In contrast, the provision of

361 additional environmetnal calcium had no effect on $\mathrm{Na}^{+}$efflux rates in acid sensitive L. fallax larvae (supplementary

362 material). Together these data suggest that tolerance of low pH environments is at least somewhat calcium-dependent.

363 However, an understanding of the mechanistic basis by which $\left[\mathrm{Ca}^{2+}\right]_{\mathrm{e}}$ allows acid-tolerant species overcome the physical

364 challenges imposed by low $\mathrm{pH}$ environs is lacking. The discovery of apical $\mathrm{pH}$ - and $\left[\mathrm{Ca}^{2+}\right]_{\mathrm{e}^{-}}$sensitive $\mathrm{Ca}^{2+}$ channels

365 (ECaC) in fish gill MR- and pavement-cells (Pinto et al., 2010; Qiu and Hogstrand, 2004; Shahsavarani et al., 2006)

366 provides a potential molecular mechanism through which epithelial function might be both disrupted by low $\mathrm{pH}$ in acid

367 sensitive species and improved in acid-tolerant species. Further work is needed to understand the mechanistic basis for

368 improved resistance to $\mathrm{Na}^{+}$efflux at low $\mathrm{pH}$ caused by $\left[\mathrm{Ca}^{2+}\right]_{\mathrm{e}}$ in amphibian larvae.

The protection of cell function and junctional integrity from the damaging effects of low $\mathrm{pH}$ water are central to

370 tolerance of acidic waters. Relative to acid naïve larvae, high levels of mucus production and secretion were seen in

371 acid-acclimated larvae. Mucus has several well established roles including the development of an unstirred layer and

372 facilitation of ion/water transport (Handy et al., 1989; Shephard, 1981; Shephard, 1982), as an immunological barrier

373 (Swidsinski et al., 2007) and in the control of gas exchange across epithelia (Wright et al., 1989). Mucus production is

374 often stimulated by low pH (Bohmer and Rahmann, 1990; Leino and Mccormick, 1984; Linnenbach et al., 1987; Walker

375 et al., 1988), where its primary function is increasing the distance between the cell surface and the environment

376 (Henriksnas et al., 2006; Phillipson et al., 2008) and neutralising hydrogen ions before they reach the apical surface of

377 epithelial cells (Holma, 1985; Phillipson et al., 2008; Stith, 1984a; Stith, 1984b). Other studies have demonstrated an

378 important role for branchial mucus in concentrating electrolytes within an unstirred layer, thereby preventing ion leak

379 from epithelia (Handy et al., 1989) and also promoting $\mathrm{Na}^{+}$uptake (Stith, 1984a; Stith, 1984b). The diffusion of low-

380 charge ions, like monovalent electrolytes, through the mucosal unstirred layer is many cases similar to that through

381 normal saline indicating that mucus is not a major obstruction to the effective uptake of these ions (Handy and Maunder,

382 2010). However, there is some evidence to suggest that the mucus layer may increase the oxygen diffusion distance

383 thereby limiting the capacity of tissues to effectively uptake oxygen (Saldena et al., 2000). Whether this translates into 
an increased cost of living at low $\mathrm{pH}$ in terms of growth rates or energy use, remains to be determined for acid water specialists like L. cooloolensis larvae.

Tolerance of low $\mathrm{pH}$ environments and the maintenance of ionic homeostasis requires that both $\mathrm{Na}^{+}$loss and $\mathrm{Na}^{+}$uptake rates be controlled. Unlike L. fallax larvae, acute exposure to low $\mathrm{pH}$ water did not result in significant inhibition of $\mathrm{Na}^{+}$uptake in L. cooloolensis larvae, and indeed in L. cooloolensis larvae reared at $\mathrm{pH} 3.5, \mathrm{Na}^{+}$uptake rates were indistinguishable from those of acid naïve larvae at $\mathrm{pH}$ 6.5. These data suggest that the capacity to limit the acute and chronic impacts of low $\mathrm{pH}$ on ion uptake mechanisms in L. cooloolensis larvae contributed to their tolerance of acid water. Although the precise mechanism is not well established, based on morphological studies of transport epithelia in salamander larvae, and on frog skin (Koefoedjohnsen and Ussing, 1958; Uchiyama et al., 2011a; Uchiyama et al., 2011b; Ussing and Zerahn, 1951), the bulk of extra-digestive $\mathrm{Na}^{+}$uptake probably occurs through membrane-bound apical epithelial $\mathrm{Na}^{+}$channels $(\mathrm{ENaC})$ at the gill surface, whose activity is coupled to the $\mathrm{Na}^{+}$gradient generated by the activity of basolateral $\mathrm{Na}^{+} \mathrm{K}^{+}$ATPase pumps (Butterworth, 2010). In other amphibian tissues, a large decrease in apical $\mathrm{pH}(<\mathrm{pH} 4)$ can cause a significant reduction in ENaC-mediated $\mathrm{Na}^{+}$transport (Harvey et al., 1988; Palmer, 1985;

Ussing and Zerahn, 1951; Zeiske et al., 1999). A reduction in apical pH is also likely to lower intracellular pH as a consequence of $\mathrm{H}^{+}$permeation, especially if cellular $\mathrm{H}^{+}$extrusion mechanisms are unable to keep up with $\mathrm{H}^{+}$infiltration rates. In vitro models of $\mathrm{ENaC}$ activity indicate that $\mathrm{Na}^{+}$transport activity is altered primarily by changing the channel open probability $\left(\mathrm{P}_{\mathrm{o}}\right)$ or by changing the abundance of ENaC pumps $(\mathrm{N})$, both of which decrease with decreasing intracellular pH (Palmer and Frindt, 1987; Zeiske et al., 1999). Although an acute reduction in pH likely lowered ENaCmediated $\mathrm{Na}^{+}$uptake in L. cooloolensis, restoration of $\mathrm{Na}^{+}$uptake capacity with prolonged exposure to low $\mathrm{pH}$ may permit long-term habitation of low $\mathrm{pH}$ environments by L. cooloolensis larvae.

Maintenance of $\mathrm{Na}^{+}$uptake in acid-acclimated L. cooloolensis larvae appears to have been accomplished by an 405 increase in the maximum $\mathrm{Na}^{+}$transport capacity, due most likely to an increase in the number of open $\mathrm{Na}^{+}$channels in the cell (as opposed to an increase in the affinity of channels for $\mathrm{Na}^{+}$which would have lowered $\mathrm{K}_{\mathrm{m}}$ ). The $\mathrm{K}_{\mathrm{m}}$ of acid naïve L. cooloolensis larvae was similar to that of L. fallax (supplementary material) suggesting that an increased 408 affinity for $\mathrm{Na}^{+}$is not likely to underpin tolerance of low $\mathrm{pH}$ environments in L. cooloolensis larvae. The ability of many acidophilic fish to maintain $\mathrm{Na}^{+}$uptake at low $\mathrm{pH}$ also appears attributable to increased capacity for $\mathrm{Na}^{+}$transport, 410 although in some species, a high transporter affinity for $\mathrm{Na}^{+}$(low $\mathrm{K}_{\mathrm{m}}$ ) can also improve $\mathrm{Na}^{+}$transport efficiency in salt411 depleting environments (Gonzalez and Preest, 1999; Gonzalez and Wilson, 2001). It is likely that in acid-acclimated $L$. 
412 cooloolensis larvae, an increase in the abundance of $\mathrm{Na}^{+}$transporting pumps is required to maintain homeostasis against

413 the persistent leak of $\mathrm{Na}^{+}$from the body that occurs in low $\mathrm{pH}$ water. In addition, $\mathrm{H}^{+}$extrusion mechanisms may be

414 upregulated to better control intracellular pH, as has been observed in zebrafish (Hirata et al., 2003; Horng et al., 2009),

415 which may improve the transport efficiency of $\mathrm{Na}^{+}$channels operating in low $\mathrm{pH}$ environments. Indeed, in the absence

416 of intracellular acidification, exposure of the extracellular components of $\mathrm{ENaC}$ to low $\mathrm{pH}$ bathing solution can improve

$417 \mathrm{ENaC}_{\mathrm{o}}$ and, therefore, $\mathrm{Na}^{+}$uptake capacity (Wichmann et al., 2019). The capacity to acclimate ion uptake rates to low

$418 \mathrm{pH}$ with prolonged exposure suggests that this system is highly plastic which allows animals to match ion uptake

419 requirement to the prevailing environment. Our findings are also consistent with several studies showing that acid-

420 induced disturbances to $\mathrm{Na}^{+}$transport mechanisms can be recovered over time in some fish species (Gonzalez and

421 Dunson, 1989a; Gonzalez and Dunson, 1989c). The capacity to manage intracellular acidification could be a major

422 factor underpinning acclimation and adaptation to low $\mathrm{pH}$ environments in L. cooloolensis larvae, however further work

423 to describe the molecular basis for $\mathrm{Na}^{+}$and $\mathrm{H}^{+}$ion transport in amphibian larvae is required.

$424 \quad$ Based on the results of this study, the tolerance of L. cooloolensis larvae to low pH may be attributed to a

425 combination of physiological and morphological factors promoting resistance to acid damage and disruption of ionic

426 homeostasis in soft acid waters. This includes a high capacity for branchial $\mathrm{Na}^{+}$uptake, tighter apposition of epithelial

427 cells of the gills and integument, and greater mucus production and secretion at the gills and body surface. These

428 attributes appear to enable L. cooloolensis larvae to tolerate acid stress better than larvae of most other amphibian

429 species. Since L. cooloolensis breeds naturally in acidic soft-water lakes, these traits are likely to reflect adaptation to

430 soft, low $\mathrm{pH}$ environments. Although many questions remain, an understanding of the molecular identity and function of

431 epithelial ion transport systems in L. cooloolensis and other similarly acid-tolerant animals is necessary to determine the

432 precise nature of the mechanisms responsible for adaptation to low $\mathrm{pH}$ water. 


\section{References}

436 Bensink, A. H. A. and Burton, H. (1975). North Stradbroke Island a place for freshwater invertebrates. Proc Royal Soc

437 QLD 86, 29-45.

438 Bohmer, J. and Rahmann, H. (1990). Influence of water acidification on amphibians. Forts Zool 38, $287-309$.

439 Butterworth, M. B. (2010). Regulation of the epithelial sodium channel (ENaC) by membrane trafficking. Biochim

440 Biophys Acta 1802, 1166-1177.

441 Daye, P. G. and Garside, E. T. (1976). Histopathologic changes in surficial tissues of brook trout, Salvelinus fontinalis

442 (Mitchill), exposed to acute and chronic levels of pH. Can J Zool 54: 2140-2155.

443 Ferreira, K. T. and Hill, B. S. (1982). The effect of low external pH on properties of the paracellular pathway and 444 junctional structure in isolated frog skin. J Physiol 332: 59-67.

445 Freda, J. (1986). The influence of acidic pond water on amphibians - a review. Water Air Soil Pollut 30: 439-450.

446 Freda, J. and Dunson, W. A. (1984). Sodium balance of larvae exposed to low environmental pH. Physiol Zool 57: 435 447443.

448 Freda, J. and Dunson, W. A. (1986a). The effect of prior exposure on sodium uptake in tadpoles exposed to low pH

449 water. J Comp Physiol B 156: 649-654.

450 Freda, J. and Dunson, W. A. (1986b). Effects of low pH and other chemical variables on the local distribution of 451 amphibians. Copeia 1986: 454-466.

452 Freda, J., Sanchez, D. A. and Bergman, H. L. (1991). Shortening of branchial tight junctions in acid-exposed rainbow 453 trout (Onchorhynchus mykiss). Can J Fish Aqua Sci 48: 2028 - 2033.

454 Glynn, A. W., Norrgren, L. and Malmborg, O. (1992). The influence of calcium and humic substances on aluminium 455 accumulation and toxicity in the minnow, Phoxinus phoxinus, at low pH. Comp Biochem Physiol C 102: $427-432$. 
456 Gonzalez, R. J., Dalton, V. M. and Patrick, M. L. (1997). Ion regulation in ion-poor acidic water by the blackskirt tetra

457 (Gymnocorymbus ternetzi), a fish native to the Amazon River. Physiol Zool 70: 428-435.

458 Gonzalez, R. J. and Dunson, W. A. (1989a). Acclimation of sodium regulation to low pH and the role of calcium in the 459 acid-tolerant sunfish Enneacanthus obesus. Physiol Zool 62: 977-992.

460 Gonzalez, R. J. and Dunson, W. A. (1989b). Differences in low pH tolerance among closely related sunfish of the genus 461 Enneacanthus. Environ Biol Fish 26: 303-310.

462 Gonzalez, R. J. and Dunson, W. A. (1989c). Mechanisms for tolerance of sodium loss during exposure to low ph of the 463 acid-tolerant sunfish Enneacanthus obesus. Physiol Zool 62: 1219-1231.

464 Gonzalez, R. J. and Preest, M. R. (1999). Ionoregulatory specializations for exceptional tolerance of Ion-poor, acidic waters in the neon tetra (Paracheirodon innesi). Physiol Biochem Zool: PBZ 72, 156-163. Negro. J Fish Biol 58: 1680-1690. in fish collected from the ion-poor, acidic Rio Negro. Physiol Biochem Zool 75: 37-47.

470 Gonzalez, R. J., Wood, C. M., Wilson, R. W., Patrick, M. L., Bergman, H. L., Narahara, A. and Val, A. L. (1998).

471 Effects of water $\mathrm{pH}$ and calcium concentration on ion balance in fish of the Rio Negro, Amazon. Physiol Zool 71: 15-22.

472 Gosner, K. L. (1960). A simplified table for staging anuran embryos and larvae with notes on identification.

473 Herpetologica 16: 183-190.

474 Handy, R. D., Eddy, F. B. and Romain, G. (1989). In vitro evidence for the ionoregulatory role of rainbow trout mucus 475 in acid, acid/aluminium and zinc toxicity. J Fish Biol 35: 737-747.

476 Handy, R. D. and Maunder, R. J. (2010). The biological roles of mucus: Importance for osmoregulation and

477 osmoregulatory disorders of fish health. In Osmoregulation and ion transport: Integrating physiological, molecular and 
478 environmental aspects, vol. 1 eds. R. D. Handy N. R. Bury and G. Flik), pp. 203-235. London: The Society for

479 Experimental Biology.

480

Harvey, B. J., Thomas, S. R. and Ehrenfeld, J. (1988). Intracellular pH controls cell membrane $\mathrm{Na}^{+}$and $\mathrm{K}^{+}$conductances and transport in frog skin epithelium. J Gen Physiol 92: 767-791.

482 Henriksnas, J., Phillipson, M., Storm, M., Engstrand, L., Soleimani, M. and Holm, L. (2006). Impaired mucus-

483 bicarbonate barrier in Helicobacter pylori-infected mice. Am J Physiol 291: G396-403.

484 Hines, H. B. and Meyer, E. A. (2011). The frog fauna of Bribie Island: An annotated list and comparison with other 485 Queensland Dune Islands. Proc Royal Soc QLD 117: 261-274.

486 Hirata, T., Kaneko, T., Ono, T., Nakazato, T., Furukawa, N., Hasegawa, S., Wakabayashi, S., Shigekawa, M., Chang, M.

487 H., Romero, M. F. et al. (2003). Mechanism of acid adaptation of a fish living in a pH 3.5 lake. Am J Physiol 284:

488 R1199-R1212.

489 Holma, B. (1985). Influence of buffer capacity and pH-dependent rheological properties of respiratory mucus on health 490 effects due to acidic pollution. Sci Total Environ 41: 101-123.

491 Horng, J. L., Lin, L. Y. and Hwang, P. P. (2009). Functional regulation of $\mathrm{H}^{+}$-ATPase-rich cells in zebrafish embryos 492 acclimated to an acidic environment. Am J Physiol 296: C682-92.

493 Ingram, G. J. and Corben, C. J. (1975). The frog fauna of North Stradbroke Island, with comments on the 'acid' frogs of 494 the Wallum. Proc Royal Soc QLD 86: 49 - 54.

495 Jagoe, C. H. and Haines, T. A. (1983). Alterations in gill epithelial morphology of yearling Sunapee trout exposed to 496 acute acid stress. T Am Fish Soc 112: 689-695.

497 Koefoedjohnsen, V. and Ussing, H. H. (1958). The nature of the frog skin potential. Acta Physiol Scand 42: 298-308.

498 Laurent, P. and Perry, S. F. (1991). Environmental effects on fish gill morphology. Physiol Zool 64: 4-25. 
Leino, R. L. and Mccormick, J. H. (1984). Morphological and morphometrical changes in chloride cells of the gills of

Pimephales promelas after chronic exposure to acid water. Cell Tiss Res 236: 121-128.

501

Linnenbach, M., Marthaler, R. and Gebhardt, H. (1987). Effects of acid waters on gills and epidermis in brown trout

502 (Salmo trutta) and in tadpoles of the common frog (Rana temporaria). In: H. Witters and Vanderborght (Eds)

503 Ecophysiology of acid stress in aquatic organisms, vol. 117, Anales Socite Royale Zoologique de Belgique Archives

504 Environmental Contamination and Toxicology, pp. 365-374.

505 Matsuo, A. and Val, A. L. (2002). Low pH and calcium effects on net $\mathrm{Na}^{+}$and $\mathrm{K}^{+}$fluxes in two catfish species from the 506 Amazon River (Corydoras : Callichthyidae). Braz J Med Biol Res 35: 361-367.

507 McDonald, D. G. (1983). The effects of $\mathrm{H}^{+}$upon the gills of freshwater fish. Can J Zool 61: 691-703.

508 McDonald, D. G., Freda, J., Cavdek, V., Gonzalez, R. and Zia, S. H. (1991). Interspecific differences in gill morphology 509 of freshwater fish in relation to tolerance of low pH environments. Physiol Zool 64, 124-144.

510 McDonald, D. G., Ozog, J. L. and Simons, B. P. (1984). The influence of low pH environments on ion regulation in the 511 larval stages of the anuran amphibian, Rana clamitans. Can J Zool 62: 2171-2177.

512 McWilliams, P. G. (1983). An investigation of the loss of bound calcium from the gills of the brown trout, Salmo trutta, 513 in acid media. Comp Biochem Physiol A 74: 107-116.

514 Meyer, E. A., Cramp, R. L. and Franklin, C. E. (2010). Damage to the gills and integument of Litoria fallax larvae 515 (Amphibia: Anura) associated with ionoregulatory disturbance at low pH. Comp Biochem Physiol A 155: 164-171.

516 Milligan, C. L. and Wood, C. M. (1982). Disturbances in haematology, fluid volume distribution and circulatory 517 function associated with low environmental pH in the rainbow trout, Salmo gairdneri. J Exp Biol 99: 397 - 415.

518 Palmer, L. G. (1985). Modulation of apical Na permeability of the toad urinary bladder by intracellular Na, Ca, and H. J 519 Membr Biol 83: 57-69.

520 Palmer, L. G. and Frindt, G. (1987). Effects of cell Ca and pH on Na channels from rat cortical collecting tubule. Am J 521 Physiol 253: F333-F339. 
522 Phillipson, M., Johansson, M. E. V., Henriksnas, J., Petersson, J., Gendler, S. J., Sandler, S., Persson, A. E. G., Hansson,

523 G. C. and Holm, L. (2008). The gastric mucus layers: constituents and regulation of accumulation. Am J Physiol 295:

524 G806-812.

525 Pinto, P., Matsumura, H., Thorne, M., Power, D., Terauchi, R., Reinhardt, R. and Canario, A. (2010). Gill transcriptome 526 response to changes in environmental calcium in the green spotted puffer fish. BMC Genomics 11: 476.

527 Qiu, A. D. and Hogstrand, C. (2004). Functional characterisation and genomic analysis of an epithelial calcium channel 528 (ECaC) from pufferfish, Fugu rubripes. Gene 342: 113-123.

529 Rosseland, B. O. and Staurnes, M. (1994). Physiological mechanisms for toxic effects and resistance to acid water: an 530 ecophysiological and ecotoxicological approach. In: C. E. W. Steinberg and R. F. Wright (eds) Acidification of 531 Freshwater Ecosystems: Implications for the Future, John Wiley and Sons, London, pp. 227-246.

532 Rowe, C. L. and Freda, J. (2000). Effects of acidification on amphibians at multiple levels of biological organization. In: 533 D. W. Sparling G. Linder and C. Bishop (ed) Ecotoxicology of Amphibians and Reptiles, SETACPress, Pensacola, pp. $534 \quad 545-571$

535 Saldena, T. A., Saravi, F. D., Hwang, H. J., Cincunegui, L. M. and Carra, G. E. (2000). Oxygen diffusive barriers of rat 536 distal colon - Role of subepithelial tissue, mucose, and mucus gel layer. Digest Dis Sci 45: 2108-2114.

537 Shahsavarani, A., McNeill, B., Galvez, F., Wood, C. M., Goss, G. G., Hwang, P. P. and Perry, S. F. (2006).

538 Characterization of a branchial epithelial calcium channel (ECaC) in freshwater rainbow trout (Oncorhynchus mykiss). J 539 Exp Biol 209: 1928-1943.

540 Shephard, K. L. (1981). The influence of mucus on the diffusion of water across fish epidermis. Physiol Zool 54: 224541229.

542 Shephard, K. L. (1982). The influence of mucus on the diffusion of ions across the esophagus of fish. Physiol Zool 55: $543 \quad 23-34$.

544 Stith, B. J. (1984a). Biochemical examination of Rana pipiens epithelial mucus. J Comp Physiol B 155: 89-96. 

B 155: 97-101.

Swidsinski, A., Loening-Baucke, V., Theissig, F., Engelhardt, H., Bengmark, S., Koch, S., Lochs, H. and Dorffel, Y. (2007). Comparative study of the intestinal mucus barrier in normal and inflamed colon. Gut 56: 343-350.

Uchiyama, M., Kumano, T., Komiyama, M., Yoshizawa, H. and Matsuda, K. (2011a). Immunohistological classification of ionocytes in the external gills of larval Japanese black salamander, Hynobius nigrescens Stejneger. J Morph 272: 1017-1024.

Uchiyama, M., Kumano, T., Konno, N., Yoshizawa, H. and Matsuda, K. (2011b). Ontogeny of ENaC expression in the gills and the kidneys of the Japanese black salamander (Hynobius nigrescens Stejneger). J Exp Zool 316B: 135-145.

Ussing, H. H. and Zerahn, K. (1951). Active Transport of Sodium as the Source of Electric Current in the Short-

555 circuited Isolated Frog Skin. Acta Physiol Scand 23: 110-127.

556 Walker, R. L., Wood, C. M. and Bergman, H. L. (1988). Effects of low pH and aluminum on ventilation in the brook trout (Salvelinus fontinalis). Can J Fish Aqua Sci 45, 1614-1622.

Wichmann, L., Dulai, J. S., Marles-Wright, J., Maxeiner, S., Szczesniak, P. P., Manzini, I. and Althaus, M. (2019). An extracellular acidic cleft confers profound $\mathrm{H}^{+}$-sensitivity to epithelial sodium channels containing the $\delta$-subunit in Xenopus laevis. J Biol Chem 294: 12507-12520.

Wilson, R. W., Wood, C. M., Gonzalez, R. J., Patrick, M. L., Bergman, H. L., Narahara, A. and Val, A. L. (1999). Ion 562 and acid-base balance in three species of Amazonian fish during gradual acidification of extremely soft water. Physiol 563 Biochem Zool 72: 277-285.

564 Wood, C. M., Matsuo, A. Y. O., Wilson, R. W., Gonzalez, R. J., Patrick, M. L., Playle, R. C. and Val, A. L. (2003). 565 Protection by natural blackwater against disturbances in ion fluxes caused by low $\mathrm{pH}$ exposure in freshwater stingrays endemic to the Rio Negro. Physiol Biochem Zool 76: 12-27. 
567 Wright, P. A., Randall, D. J. and Perry, S. F. (1989). Fish Gill Water Boundary-Layer - a Site of Linkage between

568 Carbon-Dioxide and Ammonia Excretion. J Comp Physiol B 158: 627-635.

569 Zeiske, W., Smets, I., Ameloot, M., Steels, P. and Driessche, W. V. (1999). Intracellular pH shifts in cultured kidney

570 (A6) cells: effects on apical $\mathrm{Na}^{+}$transport. Am J Physiol 277: C469-C479. 
Tables

573 Table 1. Water chemistry data for Litoria cooloolensis egg collection sites (at the time of collection). Data are presented 574 as the range of values measured ( $\min -\max )$.

\begin{tabular}{cl}
\hline Water Attribute & Range \\
\hline $\mathrm{pH}$ & $4.4-4.8$ \\
$\mathrm{Ca}^{2+}\left(\mu \mathrm{mol} \mathrm{L}{ }^{-1}\right)$ & $15-33$ \\
$\left.\mathrm{Mg}^{2+}(\mu \mathrm{mol} \mathrm{L})^{-1}\right)$ & $132-210$ \\
$\mathrm{Na}^{+}\left(\mu \mathrm{mol} \mathrm{L}^{-1}\right)$ & $74-195$ \\
$\mathrm{~K}^{+}\left(\mu \mathrm{mol} \mathrm{L}^{-1}\right)$ & $30-40$ \\
$\mathrm{Cl}^{-}\left(\mu \mathrm{mol} \mathrm{L}^{-1}\right)$ & $485-860$ \\
\hline
\end{tabular}

576

577 Table 2. Epithelial junctional morphology at the gill and integument surfaces in acid naïve and acid-acclimated Litoria

578 cooloolensis larvae. Values shown are means \pm s.e. $\mathrm{N}=5(\mathrm{df}=8)$ for all measures.

\begin{tabular}{lrrrr}
\hline \multicolumn{1}{c}{ Parameter } & \multicolumn{1}{c}{ Acid naïve } & Acid acclimated & \multicolumn{1}{c}{$\boldsymbol{t}$} & $\boldsymbol{P}$ \\
\hline Branchial Epithelium & & & & \\
Total junction length $(\mu \mathrm{m})$ & $0.64 \pm 0.03$ & $0.78 \pm 0.02$ & $\mathbf{3 . 8 8 3}$ & $\mathbf{0 . 0 0 4 7}$ \\
Tight junction length $(\mu \mathrm{m})$ & $0.37 \pm 0.03$ & $0.50 \pm 0.04$ & $\mathbf{2 . 6}$ & $\mathbf{0 . 0 3 1 6}$ \\
Minimum junction width $(\mu \mathrm{m})$ & $0.010 \pm 0.001$ & $0.012 \pm 0.001$ & 1.414 & 0.195 \\
Maximum junction width $(\mu \mathrm{m})$ & $0.028 \pm 0.001$ & $0.034 \pm 0.002$ & $\mathbf{2 . 9 6 7}$ & $\mathbf{0 . 0 3 9 1}$ \\
Integument Epithelium & & & & \\
Total junction length $(\mu \mathrm{m})$ & $0.68 \pm 0.03$ & $0.82 \pm 0.05$ & $\mathbf{2 . 4 0 1}$ & $\mathbf{0 . 0 4 3 1}$ \\
Tight junction length $(\mu \mathrm{m})$ & $0.33 \pm 0.02$ & $0.37 \pm 0.04$ & 0.8944 & 0.3972 \\
Minimum junction width $(\mu \mathrm{m})$ & $0.011 \pm 0.001$ & $0.012 \pm 0.001$ & 0.7071 & 0.4996 \\
Maximum junction width $(\mu \mathrm{m})$ & $0.031 \pm 0.001$ & $0.035 \pm 0.001$ & $\mathbf{2 . 8 2 8}$ & $\mathbf{0 . 0 2 2 2}$ \\
\hline
\end{tabular}


580 Table 3. Branchial and epidermal vesicular mucus production / secretion in acid naïve and low pH-acclimated Litoria

581 cooloolensis larvae. $\mathrm{MSV}=$ mucus secretory vesicle $; \mathrm{CCA}=$ cell cross-sectional area; $\mathrm{TMSVA}=$ total cross-sectional

582 area of mucus secretory vesicles. Values shown are means \pm s.e. $\mathrm{N}=5(\mathrm{df}=8)$ for all measures.

\begin{tabular}{|c|c|c|c|c|}
\hline Parameter & Acid naïve & Acid acclimated & $t$ & $\boldsymbol{P}$ \\
\hline \multicolumn{5}{|l|}{ Branchial Epithelium } \\
\hline MSV density (MSVs $\mu \mathrm{m}^{-2}$ ) CCA) & $0.073 \pm 0.0017$ & $0.119 \pm 0.008$ & 5.624 & 0.0005 \\
\hline TMSVA/CCA & $0.065 \pm 0.009$ & $0.181 \pm 0.012$ & 7.733 & $<0.0001$ \\
\hline $\begin{array}{l}\text { Patent MSVs per } \mu \mathrm{m} \text { of apical ce } \\
\text { membrane }\end{array}$ & $0.065 \pm 0.009$ & $0.233 \pm 0.031$ & 5.204 & 0.0008 \\
\hline \multicolumn{5}{|l|}{ Integument Epithelium } \\
\hline MSV density (MSVs $\left.\mu \mathrm{m}^{-2} \mathrm{CCA}\right)$ & $0.097 \pm 0.016$ & $0.102 \pm 0.012$ & 0.25 & 0.8089 \\
\hline TMSVA/CCA & $0.049 \pm 0.010$ & $0.156 \pm 0.025$ & 3.974 & 0.0041 \\
\hline $\begin{array}{l}\text { Patent MSVs per } \mu \mathrm{m} \text { apical cell } \\
\text { membrane }\end{array}$ & $0.108 \pm 0.018$ & $0.308 \pm 0.036$ & 4.969 & 0.0011 \\
\hline
\end{tabular}




\section{Figure Captions}

585 Fig. 1 (a) $\mathrm{Na}^{+}$flux parameters (influx $-\mathrm{J}_{\text {in }}$; efflux $-\mathrm{J}_{\text {out }}$; net flux $-\mathrm{J}_{\text {net }}$ ) in L. cooloolensis larvae tested in artificial soft 586 water (ASW) at their acclimation $\mathrm{pH}($ acid naïve larvae $=\mathrm{pH} 6.5$; acid acclimated larvae $=\mathrm{pH} 3.5)$ and for acid naïve 587 larvae, acutely at $\mathrm{pH}$ 3.5. $\mathrm{J}_{\text {in }}$ data are presented as positive values and $\mathrm{J}_{\text {out }}$ data are presented as negative values for the 588 purposes of visual representation. $\mathrm{N}=6-7$ animals per treatment group. (b) The effect of rearing $\mathrm{pH}$ and environmental $589 \mathrm{Ca}^{2+}$ level on $\mathrm{Na}^{+}$efflux rates in L. cooloolensis larvae tested at $\mathrm{pH}$ 3.5. * indicates that within each acclimation 590 treatment, value is significantly different $(\mathrm{P}<0.05)$ from the rate in 'control' $\left(40 \mu \mathrm{M} \mathrm{Ca}^{2+}\right) \mathrm{ASW} . \mathrm{N}=6-7$ per 591 treatment. (c) The dependence of $\mathrm{Na}^{+}$influx at $\mathrm{pH} 6.5$ on environmental $\mathrm{Na}^{+}$concentration. Both acclimation 592 treatments were tested at $\mathrm{pH}$ 6.5. Lines represent the output of non-linear regression analyses. $\mathrm{N}=5-7$ per $\left[\mathrm{Na}^{+}\right]$per 593 species. All data are presented as means \pm s.e

594

595 Fig. 2 Branchial (a-f) and integument (g-k) morphology and ultrastructure. (a) Gill tufts from an acid naïve larva (b)

596 Cross section of gill of L. cooloolensis larva in transverse view; (b) Gill tuft in transverse and oblique view; (c) Gill tuft 597 pavement cell with mucus secretory vesicles and mitochondria; (d) Branchial junctional complex between adjacent 598 pavement cells; (e) Apical surface of gill pavement cell coated with mucus; (f) Apical surface and cytoplasm of 599 mitochondria-rich (MR) cell; (g) Transverse section through the integument of acid naïve larva; (h) Apical surface of 600 squamous epithelial cell of the integument; (i) Attachment of basal cell layer of integument to basal lamina; (j)

601 Junctional complex between adjacent epithelial cells in the integument; (k) SEM micrograph showing apical surface of 602 integument. Abbreviations: $\mathrm{bl}=$ basal lamina; $\mathrm{cap}=$ capillary; $\mathrm{cc}=$ ciliated $\mathrm{cell} ; \mathrm{ct}$ = connective tissue; $\mathrm{d}=$ desmosome; $603 \mathrm{ec}=$ squamous epithelial cell of outer integument; $\mathrm{fp}=$ filter plates; $\mathrm{ga}=$ gill arch; $\mathrm{gt}=$ gill tuft; $\mathrm{hd}$ = hemi-desmosome; $604 \mathrm{mf}=$ mucus fuzz; $\mathrm{mr}=$ microridge $; \mathrm{msv}=$ mucus secretory vesicle $; \mathrm{mt}=$ mitochondria $; \mathrm{n}=$ nucleus; $\mathrm{pc}=$ pavement cell; $605 \mathrm{rbc}=$ red blood cell $; \mathrm{t} j=$ tight junction; $\mathrm{v}=$ velum 

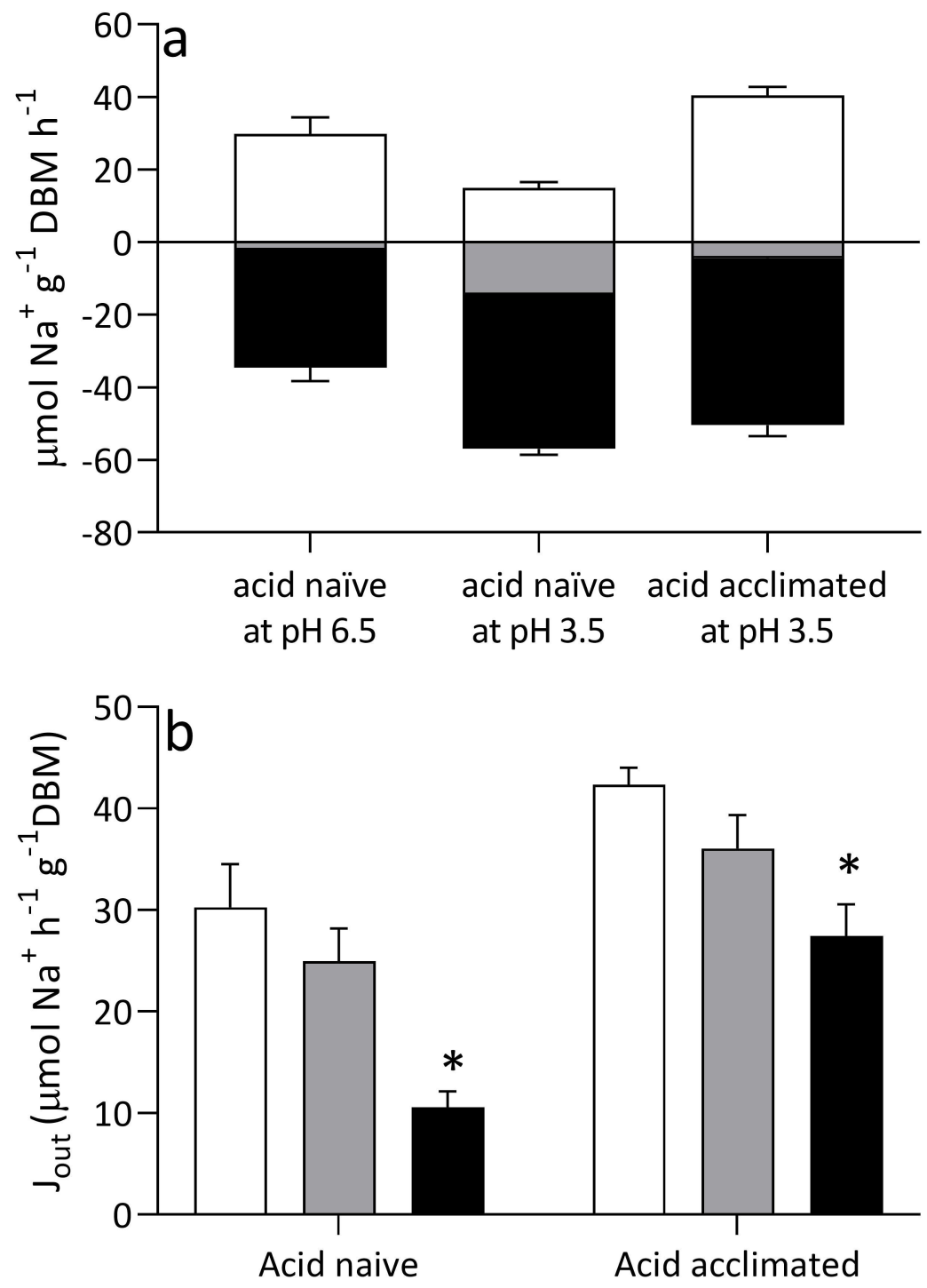

$\left[\mathrm{Ca}^{2+}\right]_{e}, \mu \mathrm{M}$

$\square 0$

$\square 0$

- 400

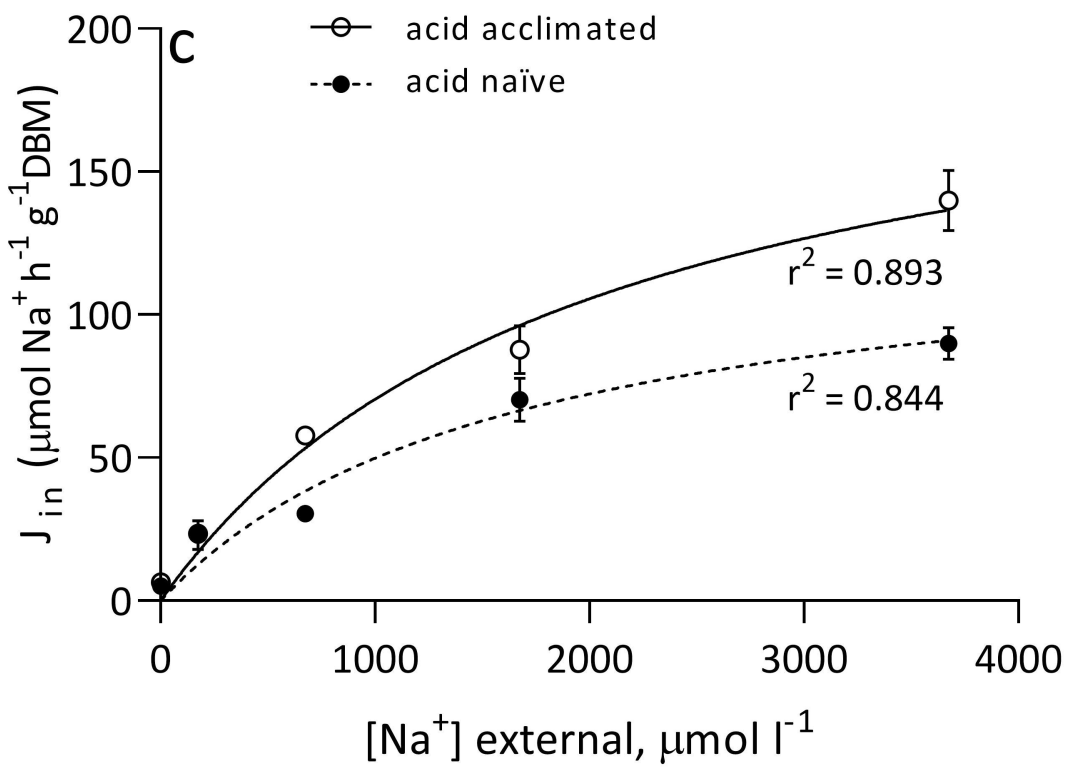




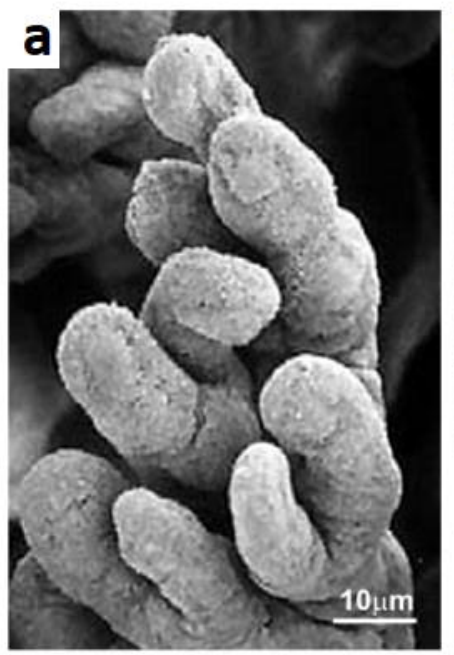

b $2 \times \mathbf{g}$

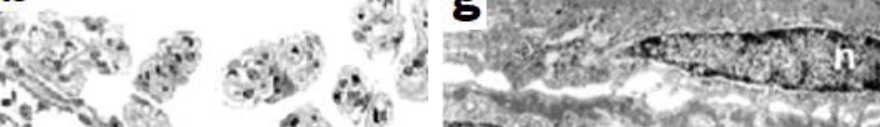
Wo 3 bl as 9

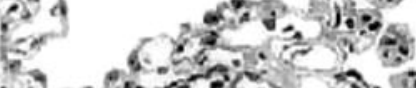
ching 0 .
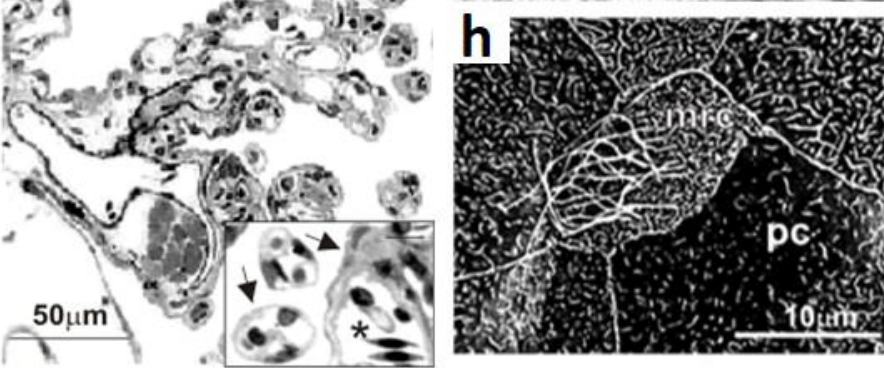

$c_{\text {min }}$ drat 20 int ins 9
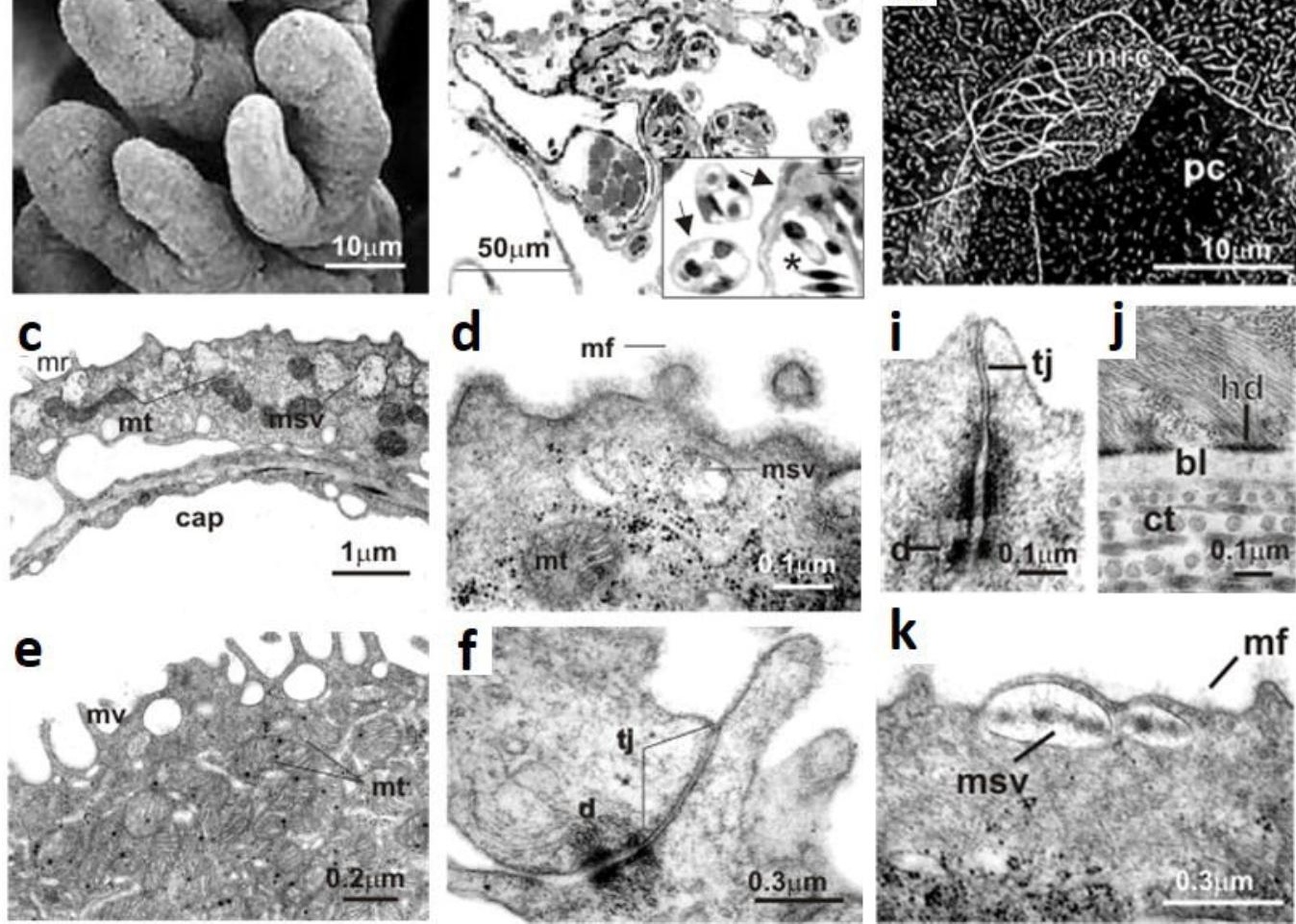